\title{
Financial Structure and Economic Growth: The Nigerian Experience, 1980-2017
}

\author{
Emeka Nkoro $P h D$ \\ Department of Economics \\ University of Port Harcourt \\ Nigeria \\ E-mail: nkoro23@yahoo.co.uk \\ Aham Kelvin Uko PhD \\ Ministry of Environment, Abia State \\ Nigeria
}

\begin{abstract}
This study investigated the role of financial structure in explaining economic growth dynamics in Nigeria using annual time series from 1981-2017. The study employed the vector error correction model (VECM) in the analysis of the data. As lead up to financial structure and economic growth relationship analysis, the competing theoretical views of bank and market based financial system and economic growth were explored. The result of the study showed that economic growth, financial development variables and the underlying control variables are cointegrated. The result of the economic growth effect of financial development showed that stock market and bankbased have a significant effect on growth. This implies that both bank-based and market-based matter in explaining economic growth dynamics. On the relationship between financial structure and economic growth, the study revealed that economic growth, financial structure and the underlying control variables have a long run relationship. The study also revealed that financial structure which captures the combination of stock market-based and bankbased has a positive significant effect on growth. A significant coefficient of financial structure implies that financial structure matters in explaining growth. Therefore, the study posits that the overall financial structure is the most useful way to assess the financial systems since both bank and stock market system matter in explaining economic growth as against bank-based versus market-based debate. Based on the empirical evidence, the study therefore recommends that there should be continuous holistic reforms of both banking and stock market simultaneously, as the development in one sector has a neglect effect on the other.
\end{abstract}

Keywords: Stock Market, Financial Market, Financial Structure, Economic Growth, Vector Error Correction Model.

\section{Introduction}

Historically, there has been debate among scholars over the role of the structure of the financial systems to economic growth. Specifically, the debate is about the relative importance of bank-based and market-based financial systems in stimulating economic growth (Gerschenkron, 1962, Stiglitz, 1985, Allen and Gale, 1999 and, Levine, 2002). Empirical studies (Hoshi et al, 1991, Mork and Nakkamura, 1999, Weinstein and Yafeh, 1998 and, Arestis et al., 2001) from developed economies of the world- the United States of America and United Kingdom show that financial structure matters in explaining economic growth. The United States of America and United Kingdom are often portrayed as market-based economies while Germany and Japan are described as bank-based economies. The results from the developed countries never provided a realistic reference point for developing countries given the critical issues of differences in development and structure of both economies. Contrarily, cross-section studies revealed that financial structure is irrelevant to economic growth. That is, neither the bank-based nor the marketbased financial system can explain economic growth; rather the studies opined that it is the overall provision of financial services (combination of banks and financial markets) that are important (Demirguc-Kunt and Levine, 1996, Levine, 2003 and, Beck and Levine, 2002). Therefore, Levine (2001) was of the view that it may be better to think not in terms of banks versus stock markets but in terms of banks and stock markets. However, Luintel and Khan (2002) showed that panel estimates often do not correspond to country-specific estimates. This could be as a result of cross-country differences and, measurement, statistical, and conceptual problems. Consequently, 
generalizations based on panel results may also be misleading at country level; hence the relationship between financial structure and economic growth remains inconclusive. These conflicting results call for country-specific study which is the concern of this study.

Recently, the emergence of global financial crisis has made developed and developing economies to shift away from free market fundamentals to a regulated economic regime. As a measure of curbing the financial crisis, the governments of these economies take up major stakes in the financial markets through the injection of funds into the institutions of the economy and, this has raised critical issues in policy formulation. Some of the developed and developing countries injected liquidity in the form of preference shares while others injected liquidity in the form of tier-2 capital(bank supplementary capital). Scholars were of the view that this decision to move from free market based economy to regulated economic regime was informed by the countries' preference for a particular financial structure based. According to Levine and Zervos (1998), developed economies show strong preference to a particular financial structure that exerts more influence on economic growth.

To mitigate the effects of 2007/2008 global financial crisis, the Nigerian government decided to bail-out only banks in the form of tier-2 capital. However, the government never considered to bail-out the capital market, especially when the stock market was not spared by the crisis. This has the capacity of promoting the bank-based financial structure over the market-based financial structure. Empirically, studies have shown that assessing whether the relationship between bank development and growth holds when controlling for stock market development hampers the ability to make policy decisions on whether the overall financial structure matters for growth as well as identifying the separate impact of banks and stock markets on economic growth (Caporale et al., 2002). Hence, the following questions are relevant: does overall financial structure influence economic growth? Which of these structures exerts more influence on economic growth? This calls for an empirical investigation.

The rest of the work is structured as follows; section two provides reviews of related and relevant literature, section three explains the method of analysis, section four focuses on the empirical results and discussions and, section five presents the conclusion and recommendations.

\section{Review of Literature}

\section{Theoretical Review}

Gerschenken (1962) was the first to classified the financial system into two categories; bank-based and marketbased financial structure and ever since this has generated serious debate among scholars. The argument has been polarized along the following lines; (1) the standard parameters or measurement for classifying a country's financial system either as bank-based or market-based; (2) which of these classifications exert more influence on economic growth; and (3) the determinants of a country's financial structure. Also, according to scholars (La Porta et al, 1997 and, Beck and Levine, 2002 and, Arestis and Luintel, 2004), the relationship between financial structure and economic development are discussed within four competing theories of financial structure. These competing theories are the bank-based view, the market-based view, the financial services view and the legal based view. These theories are examined in brief in what follows. However, before looking at the various theories of financial structure, it is proper to define financial structure. According to Stulz (2001), financial structure entails the institutions, financial technology, and rules that guide financial activity at a point in time, and also Merton (1995) added that it provides a payment system, that is, a mechanism for pooling funds, ways of transmitting resources across space and time, ways to manage uncertainty and control risk, price information to allow the economy to implement a decentralized allocation, and ways to deal with the asymmetric information problems that arise when one party to a financial transaction has information that the others do not have.

The bank-based theory lays emphasis on the positive role of banks in development and growth, and also, stresses the shortcomings of market-based financial systems. It argues that banks can finance development more effectively than markets in developing economies, and, in the case of state-owned banks, market failures can be overcome and allocation of savings can be undertaken strategically (Gerschenkron, 1962). The bank-based view stresses that a well functioning market-based systems reveal information publicly, thereby reducing incentives for investors to seek and acquire information about firms. However, banks can make investments without revealing the decision immediately in public markets and, this creates incentives for them to research firms, managers, and market conditions with positive ramifications on resource allocation and growth. This argument is that if information is going to be revealed by the market, no one is motivated to collect it. This is known as free-rider problem. As a result, competitive market system may be characterized by under-investment in information. Consequently, well developed market systems have a negative impact on the identification of innovative projects, and thereby impede efficient resource allocation (Stiglitz, 1985 and, Boot, Greenbaum, and Thakor, 1993). Also, information asymmetries are thus accentuated, more 
so in market-based rather than in bank-based financial systems (Boyd and Prescott, 1986). The distortions that emanate from asymmetric information can be eased by banks through forming long-run relationships with firms and, through monitoring, to control moral hazard. Consequently, scholars (Stiglitz, 1985 and, Bhide, 1993) assert that bank-based financial systems can produce better improvement in resource allocation and corporate governance than market-based institutions

On the contrary, the market-based theory emphasizes the advantages of well-functioning markets, and stresses the problems of bank-based financial systems. The market based theory opines that big, liquid and well-developed markets foster growth and profit incentives, enhance corporate governance and, facilitate risk management (Levine, 2002, and, Beck and Levine, 2002). The inefficiencies that are inherent in bank- based system as stressed by Levine (2002) can hinder firm innovation. For instance, once banks acquire substantial inside information about firms in the process of financing firms, banks can extract rents from firms and, firms must pay for their greater access to capital. In terms of new investments or debt renegotiations, powerful banks can extract more of the expected future profits from the firm than in a market-base system (Hellwig, 1991). This ability to extract part of the expected revenue to potentially profitable investments may limit the firm's effort to undertake innovative and profitable ventures (Rajan, 1992). Also, with the acquire substantial inside information about firms, the bank can conspire with firm managers against outsiders, which in turn hampers competition, corporate controls, the creation of new firms, and long-run economic growth (Hellwig, 1998). Market-based financial systems reduce the inherent inefficiencies associated with banks and are, thus, better at enhancing economic development and growth. In a related study, Boyd and Smith (1998) demonstrated that financial structure changes as countries go through different stages of development, and the countries become more market-based as development proceeds.

The financial services view theory is consistent with both the bank-based and the market-based views (Merton and Bodie, 1995 and, Levine, 1997). It embraces both, but downplays their importance in the sense that the distinction between bank-based and market-based financial systems matters less than was previously thought. However, according to World Bank (2001), it is the financial services itself that are by far more important than the form of their delivery. In financial services view theory, the issue is not the source of finance, but the creation of an environment where financial services are soundly and efficiently provided. The focus of this view is on the creation of better functioning banks and markets rather than on a particular type of financial structure in place. Also, the financial services theory suggests that neither banks nor markets matter, rather the combination of both. Thus, financial services view focuses on how to create better functioning banks and markets, and not the bank-based versus market-based debate. There are different components of the financial system; but do not compete each other, but ameliorate different costs like transaction and information cost in the system (Boyd and Smith, 1998, Levine, 1997 and, Demirguc-Kunt and Levine, 2001). Under these circumstances, financial arrangements focuses on ameliorating market imperfections and provide financial services that are well placed to facilitate savings mobilization and risk management, assess potential investment opportunities, exert corporate control, and enhance liquidity.

The legal-based view theory is an extension of the financial services view and also rejects the bank-based versus market-based debate. The theory stresses the role of creditor and investor rights for financial intermediation (Laporta, Lopez-de-Silanes, Shleifer, and Vishny, 1998). It is the legal system that make and enforces these rights. From this perspective, a well functioning legal system facilitates the operation of both markets and intermediaries in providing services to the private sector. It is the overall level and quality of financial services - as determined by the legal system - that improves the efficient allocation of resources and economic growth.

\section{Empirical Review}

A number of empirical studies have been conducted on relative importance of bank-based system and market-based system in stimulating economic growth. These studies were done on country-specific as well as cross-country approach.

Studies on Germany and Japan use measures of whether banks own shares or whether a company has a 'main bank' respectively (Hoshi et al., 1991, Mork and Nakamura,1999 and, Weinstein and Yafeh, 1998). These studies provide evidence that view Germany and Japan as bank-based systems. This confirms the distinction between bank based and market-based financial systems. However, a reassessment of the Japanese financial system benefits in view of the economy's poor performance in the 1990s reveals that the bank-based nature of this system is not beneficial. In response, Weinstein and Yafeh (1998) were of the view that bank dependence can lead to a higher cost of funds for firms, since banks extract rent from their corporate customers. Similarly, studies on the US and the UK provide 
evidence in favour of market-based financial systems (Wenger and Kaserer, 1998 and, Levine, 1997). Hence, the U.S. and UK were view as market-based systems. Goldsmith (1969), however, argues that the findings from the comparative analysis of bank-based system and market-based system in the case of Germany and the UK for the period 1864-1914 does not contribute to the debate since there was no significant difference in the rate of growth of the two economies. Levine (2002) reaffirmed Goldsmith's (1969) argument by concluding that financial structure did not matter much since the countries have very similar growth rates. Hence, Levine (2002) examined the relative importance of bank-based system and market-based system in stimulating economic growth using a broad crosscountry approach that allows treatment of financial system structure across many countries with different growth rates. The findings of this study support financial services view and the legal-based view as against the bank-based and the market-based views. It is the elements of a country's legal environment and the quality of its Financial Services (FSs) that are most important in stimulating general economic growth. The bank-based and the marketbased systems are supportive of the financial services and legal views and, that a better-developed financial system is what stimulates economic growth. In contrast, Tadesse (2000) examined the relative importance of bank-based systems and market-based systems in stimulating economic growth using a cross-country regression for 36 countries from 1980-1995 and found a difference between bank-based and market-based financial systems. For underdeveloped financial sectors, bank-based systems outperform market-based systems.

Demirguc-Kunt and Levine (1996), using cross-country data from forty-four industrial and developing countries for the period 1986 to 1993 to examined the relative importance of bank-based systems and market-based systems to economic growth and thereafter, concluded that countries with well-developed market-based institutions also have well-developed bank-based institutions; and vice versa, thereby supporting the view that the distinction between bank-based and market-based financial systems is of no consequence. Contrarily, Levine and Zevos (1998), adopted a cross-country regression for a number of countries covering the period 1976 to 1993 and concluded that higher stock market liquidity or greater bank development lead to higher growth, irrespective of the development of the other. In particular, market-based systems influence growth through the provision of liquidity that enables investment to be less risky, such that companies have access to capital through liquid equity issues (Harris, 1997). Summarily, the World Bank (2001) reached a conclusion that the evidence should be interpreted as clearly suggesting that both the development of bank-based and market-based financial systems promote economic growth and, each can complement the other.

Furthermore, Saibu, Bowale and Akinlo (2009) investigated the relationship between economic growth and financial structure, i.e.,the degree to which an emerging economy is market based or bank based. In particular, this study empirically assessed the competing theoretical views of financial structure and economic growth dynamics in Nigeria using vector error correction model over a 30 year period. The result shows that changes in financial structure in Nigeria have no significant influence on real growth rate. The result shows further that despite the negative effect of bank-market on economic growth, bank-market has positive effect on stock market development hence suggesting that neither the bank-market nor stock market based system is a dominant factor on economic growth in Nigeria. Therefore, the controversy between bank based and market based is not a Nigerian phenomenon, as both theoretical positions are not supported by evidence. Rather, the results are more consistent with the financial services view that both bank and stock market are relevant to the growth of an emerging economy like Nigeria. Similarly, Ujunwa, Salami, Nwakoby and Umar (2012) examined the impact of competing financial structure theories on economic growth in Nigeria for the period, 1992-2008 using the Ordinary Least Square (OLS) regression approach. The results showed that despite the non-significant influence of bank-based theory and legal-based theory, both have positive effect in promoting economic growth while the result shows further that market-based theory and the financial service theory were non-significant but exhibited negative influence in promoting economic growth. These results are consistent with Saibu, Bowale and Akinlo (2009) findings. Also, Olofin and Afangideh (2009) investigated the role of financial structure in economic development in Nigeria using aggregate annual data from 1970 to 2005. It developed a small macro econometric model to capture the interrelationships among aggregate bank credit activities, investment behaviour and economic growth given the financial structure of the economy. Three stage least square estimation technique was adopted. The result shows that financial structure has no direct effect on output growth but through bank credit and investment activities. The finding from the simulation results equally confirmed that what matters is overall financial development and not bank-based versus market-based debate. This supports financial services theory. The simulation result also confirmed that both capital market-based and bankbased financial development have similar impact on the real sector of the economy, thereby relegating the capital 
market-based versus bank-based debate to the background, and favour the combination of the both. Luintel, Khan, Arestis and Theodoridis (2008) examined the relationship between financial structure and economic growth using a sample of fourteen countries for the period 1976 to 2005. Fully Modified OLS (FMOLS) of Phillips and Hansen (1990) was employed and, thorough scrutiny of the study results was done through bootstrap exercises. Several hypotheses about the prospective role of financial structure and financial development on economic growth were tested. These exercises were done due to the fact that much of the recent empirical work that analyzed multi-country dataset at firm-, industry- and aggregate-levels utilizing the panel and/or pure cross-section frameworks concluded that financial structure is irrelevant. Hence, Luintel, Khan, Arestis and Theodoridis (2008) were among scholars that have raised doubts about the irrelevant of financial structure in explaining growth in multi-country studies. In addressing this concern the study analyzed 14 low-and-middle income countries using both time series and dynamic heterogeneous. Evidence from the study shows that cross-country heterogeneity cannot be addressed and this mark important cross-country differences in the relationship under investigations. This shows that data from the sampled countries cannot be pooled. This also underpins our focus on a time series analysis. The study also revealed that panel and the country-specific parameters (estimates) do not correspond hence limiting the economic value of panel estimates. Furthermore, the study revealed that various countries in the panel study are on the balanced growth path raising concern on pooled regressions. Overall, the study reveals that the irrelevance of financial structure in panel or cross section studies may be because they do not sufficiently account for the cross country heterogeneity. Nevertheless, the study shows that output level, capital stock, financial structure and financial development variables are co-integrated. Also, the study reveals that, financial structure and financial development significantly explain economic growth for the majority of the sampled countries, this holds under time series and panel estimates.

The literature reviewed suggests that the issue between financial structure and its impact on economic growth is yet to be resolved. Specifically, the argument on the relative importance of bank based and market based to economic growth is still on. Cross-country and country-specific studies financial structure and its impact on economic growth have been carried out but the controversy still persists. However, evidence on Nigerian economy is still scanty except on cross-sectional basics where Nigerian data are lumped up with other countries. Therefore, it is imperative to examine whether changes in financial structure or the overall financial systems impact on a typical developing economy like Nigeria, whose overall financial sector is expanding both in size and complexities. This study intends to contribute to the existing literature. This is done by utilizing annual time series data from 1981-2017 to develop a model that captures the relationships between financial structure variables and economic growth.

\section{Methodology}

\subsection{Data and Sources}

The annual data for this study were basically from secondary sources. Specifically, the data were from Central Bank of Nigeria (CBN) statistical bulletin, various issues, Securities and Exchange Commission, Nigeria (2017) and World Development Indicators (WDI). The annual data covers the sample period, 1981-2017. The choice of the period and frequency of data was because of availability of data. The variables used in the model specification are real gross domestic product growth which is used to measure economic growth as the dependent variable while labour employed, represented by percent growth in labour force participation, $\mathrm{K}_{\mathrm{p}}$ is the physical capital or investment, captured by log gross fixed capital formation as percent of GDP, financial structure, represented by the stock market capitalization ratio over credit to private sector ratio, degree of openness, government expenditure/GDP and inflation served as the explanatory variables.

\subsection{Model Specification}

\subsubsection{Analytical Framework}

The analytical framework of this study is based on the neoclassical model of economic growth which stresses capital and labour as the main determinants of output (economic growth). Technological progress is generally acclaimed as an additional determinant of output and it comes into the model as a time related trend ( $\mathrm{t}$ ). According to the neoclassical model, the relationship between economic growth and these variables is expressed in the form of a production function. Therefore, the conventional form of Cobb Douglas production function as in Saibu et al, (2009) is adopted as basis. Thus:

$$
Y=A L^{\alpha} K^{\beta}
$$

Where $\alpha, \beta>0$ 
Where $\mathrm{Y}$ represents output produced, $\mathrm{L}$ is the utilized labour, $\mathrm{K}$ is the utilized capital and $\alpha, \beta$ and are the parameters representing the output elasticity of each input (labour and capital). Theoretically, it is argued that the labour and capital are embodiment of several other inputs that are also directly influencing output growth even when the traditional inputs are unchanged; hence there is need for simple modification of eqn 1 . Thus, one of such possible inputs is the financial resources committed into production process. In line with this argument, capital can be decomposed into fixed physical $\left(\mathrm{K}_{\mathrm{p}}\right)$ and, financial $\left(\mathrm{K}_{\mathrm{f}}\right)$ resources which are generated from the financial sector (Saibu et al, 2009). Thus:

$$
Y=A L^{\alpha} K_{p}{ }^{\theta} K_{f}^{\varphi} \quad \text { Where } \alpha,(\beta=\theta+\varphi) \geq 0
$$

$K f$ is the level of financial capital utilized in the production process, and it is an increasing function designed to capture the channel through which financial factors raise the rate of return on investment and subsequently output. The model in equation (2) is transformed into partial log linear form:

$$
\operatorname{InY}=\operatorname{InA}+{ }_{a} L+{ }_{\theta} \operatorname{In} K_{p}+{ }_{\varphi} K_{f}+U_{t}
$$

Where $U$ represents other variables that might also be impacting on the growth of output.

Apart from the labour, investment and financial factors, evidences from previous studies revealed that many other factors influence economic growth. Saibu et al, (2009) indentified public investment, degree of openness and inflation as other factors influencing growth. The model of the study differs from Saibu et al, (2009) with little modification in area of the determinant variables. This study incorporated into the model total government expenditure and gross fixed capital formation as against public investment on infrastructure and gross private investment in Saibu et al, (2009).

In line with the objectives of the study which is investigating the competing views on the role of the financial structures (bank-based view, market-based view, financial service view and the legal system service view) in promoting economic growth in Nigeria, equation (3) is modified. Therefore the estimated equation is of the form:

$$
\operatorname{InRGDPi}=B O+B_{1} G L F+B_{2} \operatorname{Inkp}+B_{3} K_{f}+B_{4} C+U t
$$

Where RGDPi is the real gross domestic product, GLF is the labour employed, represented by percent growth in labour force participation(GLP), $\mathrm{K}_{\mathrm{p}}$ is the physical capital (captured by log gross fixed capital formation as percent of GDP(DI)), $\mathrm{K}_{\mathrm{f}}$ captures respective financial structures or financial development variables (bank sector credit to private sector as a percentage of GDP(BCP_R) and stock market capitalization as a percentage of GDP(SMC_R)) and, $\mathrm{C}$ captures the control variables (degree of openness(OPENN), log government expenditure/GDP(TGEX_R) and inflation(INF)). The degree of openness is measured as the ratio of total trade to GDP (Foreign Trade/GDP) and is used as the openness of the economy, government expenditure/GDP is government expenditure as a ratio of GDP and inflation is the log difference of composite consumer price indices. Also, to investigate the overall role of financial structure (combination of the competing views) in promoting economic growth in Nigeria hence, the estimated equation is of the form:

$$
\operatorname{InRGDP_{i}}=B 0+B_{1} \operatorname{In} G L F+B_{2} \operatorname{InDI}+B_{3} F S_{-} R+B_{4} \operatorname{InC}+U_{t}
$$

The variables definitions remain the same with eqn 4 except DI and FS_R. DI is the log gross fixed capital formation as percent of GDP which captures investment. FS_R captures the overall financial structure. FS_R is defined as the stock market capitalization ratio over credit to private sector ratio. That is, FS_R a conglomerate index of stock market activity and bank activity. A significant FS_R implies that financial structure matters in determining economic growth while an insignificant of FS_R implies that financial structure is inconsequential in determining growth.

\subsubsection{Method of Data Analysis}

As this study is based on time series data so the first step is to check whether the series are stationary or not. Augmented Dickey-Fuller (1979)(ADF) and Phillips-Peron (1988)(PP) tests are used for testing stationarity. If the 
ADF and Phillips-Peron statistics confirm that, there exist or no unit roots in the series, next is to verify whether long run relationship exists between financial structure and economic growth. In doing this, it is the features of the series that determine the cointegration test technique to be adopted. If all the variables are stationary at level, the simple regression technique is adopted, hence no need to test for long relation of the series or if the stationarity of variables are mixed, $\mathrm{I}(0), \mathrm{I}(1)$, the autoregressive distributed lag bound technique is employed or if all the series are integrated at I(1) then Johansen and Juselius co-integration technique (1991) is adopted. Also, the number of the cointegrating equations determines the model to adopt. If the number of cointegrating equation is one, the Error Correction model (ECM) is employed or if the number of cointegrating equation is more than one, Vector Error Correction model (VECM) is employed or if there is no cointegrating equation, the Unrestricted Vector Autoregressive model (VAR) is adopted. However, given the feature of the stationarity of the series and the order of the VAR using Akaike's Information Criterion, Johansen and Juselius co-integration technique (1991) is adopted to identify the long-run equilibrium relationship, if it exists. The presence of such relationship rules out spurious relationship among the underlying variables. Having established more one cointegrating vector, the Vector Error Correction Model (VECM) model is applied to check what happens within the short run and long run. Also, to establish if there is causality between the different types of financial structure (or overall structure) and economic growth, the Vector Error Correction (VEC) Granger causality test is used. The vector error correction (VECM) model is expressed as follows:

$$
\Delta Y_{t}=\mu+\Gamma_{1} \Delta Y_{t-1}+\cdots+\Gamma_{p-1} \Delta Y_{p-1}+\alpha E C M_{t-1}+\epsilon_{t}
$$

Where $\Delta$ is a difference operator and $\mathrm{Y}$ is a vector of $\mathrm{I}(1)$ variables that are involved in this study, $\boldsymbol{\epsilon}_{\boldsymbol{t}}$ is a vector of white noise errors, ECM is the residuals of the long-run model lagged one period, and $\boldsymbol{\alpha}$ is a vector of adjustment coefficients. These latter indicate the adjustment to long-run equilibrium. They should be statistically significant and have a negative sign. The Granger causality among these variables is tested through the vector error correction model.

\section{Results and Discussions}

\subsection{Test Results}

\subsubsection{Unit Roots Test}

The time series properties of the data were evaluated by using Augmented Dickey Fuller (ADF) and Phillips-Perron (PP) procedures for the presence of unit roots. The unit roots test results reported in Table 1 show that the variables are non-stationary at level but unequivocally stationary at first difference, implying that they are I(1) properties. This is deduced from the fact that the absolute values of the ADF/PP test statistics of the variables at levels are less than the absolute value of the critical values of the $\mathrm{ADF} / \mathrm{PP}$ at 1 or 5 percent significance level. However, the reverse is the case for the first differences of the variables.

Table 1: ADF/PP Statistics for Testing Unit Roots in the Variables

\begin{tabular}{|c|c|c|c|c|c|}
\hline \multirow[b]{2}{*}{ Variable } & \multirow[b]{2}{*}{ Series } & \multicolumn{2}{|c|}{ ADF-Test } & \multicolumn{2}{|c|}{ PP-Test } \\
\hline & & At Level & $1^{\text {st }}$ Diff & At Level & $1^{\mathrm{st}}$ Diff \\
\hline Economic Growth & $\overline{R G D P}$ & 0.0321 & $-3.3397 *$ & 0.8578 & $-3.1798^{*}$ \\
\hline Labour & GLF & -1.8314 & $-9.4417 *$ & -3.0905 & $-9.4417^{*}$ \\
\hline Investment & DI & -2.8903 & $-5.5399 *$ & -2.9000 & $-5.1218^{*}$ \\
\hline Bank Credit to Private Sector Ratio & BCP_R & -0.8169 & $-6.3365^{*}$ & -0.8169 & $-6.3370^{*}$ \\
\hline Stock Market Cap Ratio & SMC_R & -1.7674 & $-5.8978 *$ & -1.5751 & $-9.5326^{*}$ \\
\hline Inflation Rate & $\mathrm{INF}$ & -2.8593 & $-6.1392 *$ & -2.7318 & $-9.3995^{*}$ \\
\hline Total Government Expenditure & TGEX_R & -2.4359 & $-8.5933 *$ & -2.2520 & $-8.5247^{*}$ \\
\hline Degree of Openness & OPENN & -1.7873 & $-7.4157 *$ & -1.6699 & $-7.5446^{*}$ \\
\hline Financial Structures & FS_R & -2.6408 & $-5.8248 *$ & -2.6408 & $-7.1130^{*}$ \\
\hline & $1 \%$ & -3.6268 & -3.6329 & -3.6268 & -3.6329 \\
\hline Critical Values & $5 \%$ & -2.9458 & -2.9484 & -2.9458 & -2.9484 \\
\hline
\end{tabular}

Source: Calculations by Authors using Eviews 9. *significant at 1\% and $5 \%$ level 


\subsubsection{Cointegration Test}

Since all the variables are integrated of order one, next is to examine the long run relationship of the variables by using Johansen and Juselius co-integration procedure. This test is carried out by defining the vector $Z t=\left[X_{I t}, X_{2 t}\right]$ as the set of all variables in equation (4) wherein all variables could potentially be endogenous.

Table 2: Johansen and Juselius Co-integration Tests

\begin{tabular}{cccc}
\hline \multicolumn{1}{l}{ Eigenvalue } & Trace Statistic & Critical Value (5\%) & No. of CE \\
\hline Model 1: LRGDP GLF LDI BCP_R SMC_R LTGEX_R OPENN INF & \\
\hline 0.860335 & 235.9368 & 159.5297 & None * \\
\hline 0.783126 & 167.0389 & 125.6154 & At most $*^{*}$ \\
\hline 0.660958 & 113.5436 & 95.75366 & At most $*^{*}$ \\
\hline 0.543581 & 75.68660 & 69.81889 & At most 3 \\
\hline 0.511029 & 48.23455 & 47.85613 & At most 4 \\
\hline 0.378007 & 23.19372 & 29.79707 & At most 5 \\
\hline 0.144209 & 6.574798 & 15.49471 & At most 6 \\
\hline 0.031612 & 1.124278 & 3.841466 & At most 7 \\
\hline
\end{tabular}

$*(* *)$ denotes rejection of the hypothesis at $5 \%(1 \%)$ significance level.

Trace test indicates 5 cointegrating eqn(s) at the 0.05 level

Source: Calculations by Authors using Eviews 9.

Table 3: Johansen and Juselius Co-integration Tests

\begin{tabular}{cccc}
\hline \multicolumn{1}{l}{ Eigenvalue } & Trace Statistic & Critical Value (5\%) & No. of CE \\
\hline Model 2: LRGDP GLF LDI FS_R LTGEX_R OPENN INF & & \\
\hline 0.749327 & 146.2738 & 125.6154 & None * \\
\hline 0.556757 & 97.84755 & 95.75366 & At most 1 * \\
\hline 0.516777 & 69.37022 & 69.81889 & At most 2 \\
\hline 0.476369 & 43.91552 & 47.85613 & At most 3 \\
\hline 0.361429 & 21.27165 & 29.79707 & At most 4 \\
\hline 0.119897 & 5.573383 & 15.49471 & At most 5 \\
\hline 0.031031 & 1.103296 & 3.841466 & At most 6 \\
\hline
\end{tabular}

$*(* *)$ denotes rejection of the hypothesis at $5 \%(1 \%)$ significance level. Trace test indicates 2 cointegrating eqn(s) at the 0.05 level

Source: calculations by Authors using Eviews 9.

Tables 2 and 3 reveal that there exists co-integration among the variables. That is, there exist a long run relationship among the variables in Tables 2 and 3. Given the existence of more than one cointegrating vectors in both models, it is pertinent to adopts Vector Error Correction model (VECM) for the analysis of the relationship between financial structure and economic growth.

\subsection{The Pairwise Correlation Result}

As lead up to the multivariate analysis of the model, the correlation among the underlying variables is examined. Table 4 shows that economic growth is only positively correlated with FS_R, BCP_R and SMC_R measures. This is in line with the theoretical underpinnings which suggest that finance promotes economic growth. FS_R, BCP_R and SMC_R have correlation coefficient of $46 \%, 87 \%$ and $83 \%$ respectively with economic growth.

Table 4: Correlation Coefficients

\begin{tabular}{lccccccccc}
\hline & LRGDP & GLF & LDI & FS_R & BCP_R & SMC_R & LTGEX_R & OPENN & INF \\
\hline LRGDP & - & 0.260 & -0.103 & 0.459 & 0.874 & 0.832 & -0.440 & -0.379 & -0.337 \\
\hline GLF & 0.260 & - & 0.613 & -0.076 & 0.429 & 0.241 & -0.559 & -0.673 & -0.208 \\
\hline LDI & -0.103 & 0.613 & - & -0.400 & 0.195 & -0.119 & -0.377 & -0.633 & -0.074 \\
\hline FS_R & 0.459 & -0.076 & -0.400 & - & 0.117 & 0.787 & -0.188 & 0.244 & -0.270 \\
\hline BCP_R & 0.874 & 0.429 & 0.195 & 0.117 & - & 0.682 & -0.495 & -0.683 & -0.281 \\
\hline SMC_R & 0.832 & 0.241 & -0.119 & 0.787 & 0.682 & - & -0.435 & -0.292 & -0.370 \\
\hline LTGEX_R & -0.440 & -0.559 & -0.377 & -0.188 & -0.495 & -0.435 & - & 0.579 & 0.235 \\
\hline OPENESS & -0.379 & -0.673 & -0.633 & 0.244 & -0.683 & -0.292 & 0.579 & - & 0.273 \\
\hline INF & -0.337 & -0.208 & -0.074 & -0.270 & -0.281 & -0.370 & 0.235 & 0.273 & - \\
\hline SOUC? & & &
\end{tabular}

Source: Calculations by Authors using Eviews 9. 


\subsection{Vector Error Correction Model (VECM)}

To analysis the long and short run relationship between the variables in the models and economic growth, the study employed VECM. The VECM results are as follows:

\subsubsection{Economic Growth Effects of Financial Development}

This sub-section investigates the relative contribution of both bank and stock market system with control variables in explaining growth. Table 5 shows the result.

Table 5: Long Run Model of Economic Growth Determinants

\begin{tabular}{lccc}
\hline \multicolumn{1}{c}{ Variable } & Coefficient & Standard Error & t-Statistics \\
\hline C & -15.38154 & & \\
\hline GLF & 0.022182 & 0.39784 & 0.05576 \\
\hline LDI & 1.855416 & 0.15656 & $11.8515^{*}$ \\
\hline BCP_R & -0.217988 & 0.01066 & $-20.4443^{*}$ \\
\hline SMC_R & 10.91057 & 0.90122 & $12.1065^{*}$ \\
\hline LTGEX_R & 0.816945 & 0.11539 & $7.08004^{*}$ \\
\hline OPENNESS & 0.745104 & 0.33840 & $2.20186^{* *}$ \\
\hline
\end{tabular}

Note. $*(* *)$ indicate significance at $1 \%(5 \%)$

Source: calculations by Authors using Eviews 9.

The essence of this sub-section is to examine the significance of bank and stock market activity on economic growth and, whether both are substitute or complement in the long run. Table 4 shows that bank activity has a negative effect on economic growth while the stock market activity has a positive effect on economic growth. The implications of the signs of the financial development variables are $\mathrm{x}$-rayed below.

From Table 5, the bank activity has a negative effect on economic growth in the long run. This result is inconsistent with the bank-based financial structure theory which posits that the unique role of banks in identifying good projects, mobilizing resources, monitoring managers and managing risks promotes economic growth. The result is consistent with Ayadi et al. (2013) who also found a negative relationship between bank sector and growth and, attributed it to deficiencies in credit allocation in the economy. The negative relationship does not mean that the banking sector is underdeveloped rather it could be explained by credit allocation problem in Nigeria. Most borrowings in Nigeria are not channelled to productive ventures but rather for consumption spending which does not promote economic growth in the long run. Also, most banks are engaging less in financial intermediation activities. For instances, some have become selling agencies, revenue collectors and they are now facilitators of black market forex dealing. Hence, bank engages more in non-financial intermediation and unproductive activities than their traditional banking function of intermediating fund from the surplus sector to deficit sector. Therefore, the bank activities in relation to economic performance have negative effect.

Table 5 reveals that the stock market activity has a positive effect on economic growth in the long run. This is consistent with market based theory which opines that big, liquid and well-developed markets foster growth and profit incentives; enhance corporate governance and, facilitate risk management (Levine, 2002, and, Beck and Levine, 2002). The inefficiencies that are inherent in bank- based system as stressed by (Levine, 2002) are being reduced by Market-based financial systems. It is argued that there is an inverse relationship between stock (bond) price and the interest rate. If the bank interest rate is high, then investor who requires funds will prefer going to the stock market to raise fund since the cost of raising fund in the bank is very high. Hence, a market-based financial system is better at enhancing economic growth.

On whether both are substitute or complement, the result from Table 5 reveals that the signs on both the bank and stock market variables are different; the bank activity sign is negative while stock market sign is positive which implies that both are substitute. Hence, this supports the hypothesis that bank and stock market are substitute. This result collaborates with Saibu et al, (2009) and, inconsistent with The World Bank (2001). The reasons for this result could be based on theoretical argument and problems in credit allocation. However, it is proper to focus on the significance or otherwise of the coefficients of financial development variables, rather than their signs (Arestis et al, 2004 and, Olofin and Afangideh, 2009). Given the bank and market system variables, it shows that the both are significantly influencing economic growth in Nigeria. The significant of the coefficients of both bank and stock market imply that both systems matter while the reverse is the case. However, to confirm whether both bank and stock market system matter or not in explaining economic growth in Nigeria, the relationship between financial structure (overall financial system which combined both systems) and economic growth was examined (see section $4.5)$. 
Table 6: Multivariate VECM Causality Test (Short Term)

\begin{tabular}{|c|c|c|c|c|}
\hline \multirow{2}{*}{$\begin{array}{l}\text { Dependent } \\
\text { Variable }\end{array}$} & \multicolumn{3}{|c|}{ Independent variable } & \multirow[t]{2}{*}{ ECT(-1) } \\
\hline & D(LRGDP) & $\overline{\mathrm{D}\left(\mathrm{BCP} \_\mathrm{R}\right)}$ & $\mathrm{D}(\mathrm{SMC}$ _R $)$ & \\
\hline $\mathrm{D}(\mathrm{LRGDP})$ & - & 0.3306 & 0.2095 & $-0.042689 * * *$ \\
\hline D(BCP_R $)$ & $0.0205 * *$ & - & $0.0008 *$ & $4.142087 *$ \\
\hline$\overline{\mathrm{D}\left(\mathrm{SMC} \_\mathrm{R}\right)}$ & 0.8917 & 0.2370 & - & 0.031604 \\
\hline
\end{tabular}

*Significant at $1 \%, * *$ significant at $5 \%$ and $* * *$ significant at $5 \%$

Source: calculations by Authors using Eviews 9.

After exploring the long run association between economic growth and measures of financial development, we now proceed to multivariate Granger causality test based on VECM. At this juncture, it is important to note that the documented cointegration among the variables suggests only their long run association and, while it implies causality but does not reveal the directions of causation among them. Table 6 reports the multivariate causalities among the economic growth and financial variables. It examines the short run line of causation between economic growth and financial structure and, other variables. Also, Multivariate VECM causality helps to determine how the underlying variables enter the model. Relatively, the Multivariate VECM causality is preferred to VECM system equation in differences since the interpretation of VECM system equation is difficult.

Table 6 shows that there is no any causation in short term running from financial development variables (BPC_R and SMC_R) to economic growth (LRGDP) in the Nigeria economy while there is long run causality between financial development variables and economic growth. Also, the result reveals that there is a short-run interaction between LRGDP and BPC_R, which runs from economic growth (LRGDP) to financial development (BPC_R). This finding supports the view, the growth-led finance hypothesis. Based on this view, the financial development in Nigeria follows economic growth.

The adjustment coefficients (ECT(-1)) in Table 6 show the speed of adjustment towards equilibrium path. As shown in the Table, the coefficient of adjustment in LRGDP equation is rightly signed and statistically significant at 10 percent significance level. This shows that the underlying variables are cointegrated and a long run equilibrium relationship exists between the variables. The result also reveals that the LRGDP adjust by 4 percent every year whenever the variables drift away from the long run equilibrium, which is quite slow. On the other hand, the coefficients adjustment in equation BPC_R is wrongly signed and significant while that of SMC_R is wrongly signed and not significant.

\subsection{Model Appraisal}

Model Appraisal is aimed at validating the parameter outcomes achieved by the estimated model. The Appraisal is important because if the residuals from the estimated model are problematic, it then means that the model is not efficient and the parameter estimates may be biased. Some of the tests carried out on the model are; AR roots, serial correlation, normality and hetroscedasticity. The results are presented below.

\section{AR Roots Test}

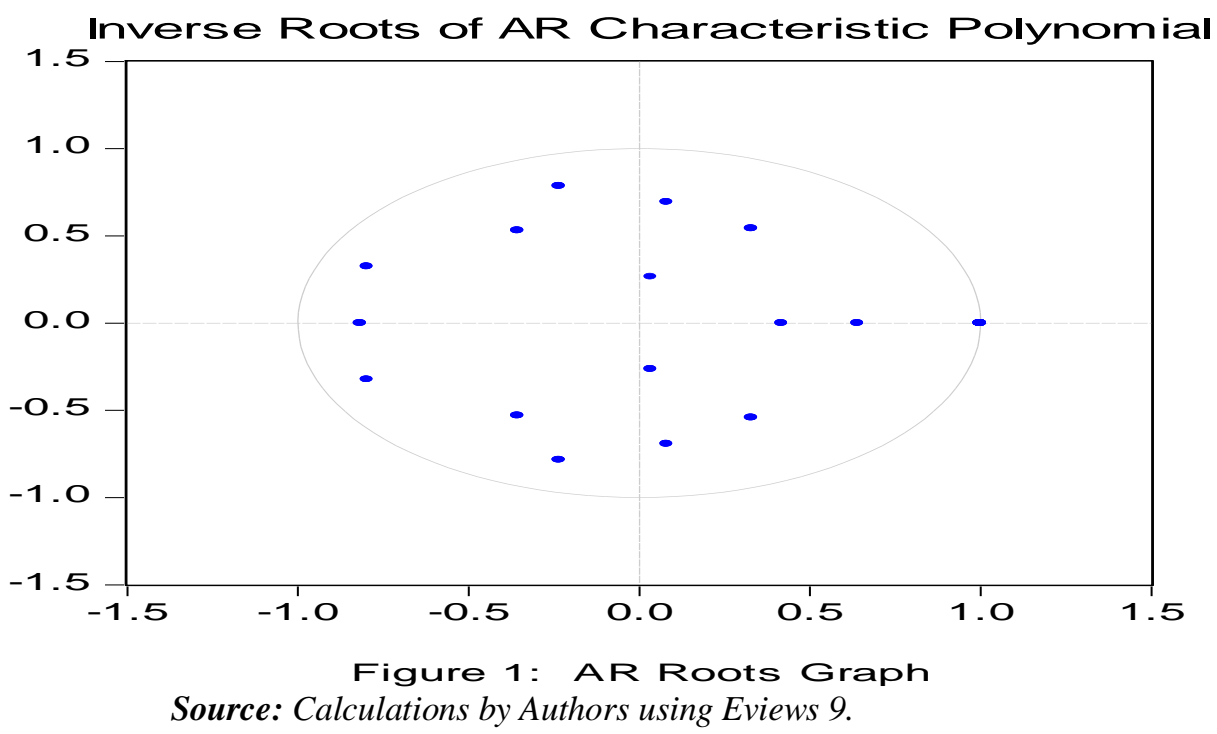


The AR roots test result in Figure 1 indicates that the estimated model is stationary since there are no roots lying outside the unit cycle, meaning that the model is stable.

Table 7: VEC Residual Serial Correlation LM Tests

\begin{tabular}{lll}
\hline Lags & LM-Stat & Prob \\
\hline 1 & 36.77971 & 0.9008 \\
\hline 2 & 47.05216 & 0.5524 \\
\hline
\end{tabular}

* Probs from chi-square with 49 df. ** Null Hypothesis: no serial correlation at lag order $\mathrm{h}$

Source: calculations by Authors using Eviews 9.

The serial correlation LM test result of zero probability value indicates the presence of serial correlation while high probability of the LM statistic indicates no serial correlation. In Table 7 the probability of 0.5524 at lag 2 is high; therefore, the null hypothesis is rejected and concludes that there is no serial correlation among the underlying variables.

Table 8: Residual Normality Test

\begin{tabular}{lcc}
\hline & Chi-sq & P value \\
\hline Skewness & 0.365750 & 0.5453 \\
\hline Kurtosis & 0.031476 & 0.8592 \\
\hline Jarque-Bera & 0.397226 & 0.8199 \\
\hline
\end{tabular}

*Null Hypothesis: residuals are multivariate normal

Source: calculations by Authors using Eviews 9.

Table 8 reveals a clear indication of normal distribution. This is because all the probabilities are above 5\% and $10 \%$, hence the null hypothesis of normality is rejected.

Table 9: Hetroscedasticity Test (White test with no cross terms)

\begin{tabular}{ccl}
\hline & Joint Test: & \\
\hline Chi-sq & Df & Prob. \\
\hline 866.9252 & 840 & 0.2526 \\
\hline
\end{tabular}

*The null hypothesis: there is no heteroskedesticity

Source: calculations by Authors using Eviews 9.

Table 9 shows that the null hypothesis cannot be rejected since the probability $(0.2526)$ is greater than $5 \%$ and $10 \%$. This, therefore, means that there is no model misspecifications and hence can be relied on.

\subsection{Economic Growth Effects of Financial Structure}

This sub-section examines the effect of financial structure (the overall financial system) on growth. Table 10 shows the result.

Table 10: Long Run Model Effect of Financial Structure on Economic Growth

\begin{tabular}{lccc}
\hline \multicolumn{1}{c}{ Variable } & Coefficient & Standard Error & t-Statistics \\
\hline C & -2.162760 & & \\
\hline GLF & -15.28466 & 4.31484 & $-3.54235^{* *}$ \\
\hline LDI & 10.65363 & 1.28779 & $8.27280^{*}$ \\
\hline FS_R & 222.2282 & 57.9683 & $3.83362^{* *}$ \\
\hline LTGEX_R & 0.122002 & 1.41658 & 0.08612 \\
\hline OPENN & 10.81927 & 2.88405 & $3.75142^{* *}$ \\
\hline INF & -0.036314 & 0.01505 & $-2.41233^{* *}$
\end{tabular}

Note. $*(* *)$ indicate significance at $1 \%(5 \%)$

Source: calculations by Authors using Eviews 9. 
From Table 10, Financial structure (FS_R) is positively and significantly related to economic growth in Nigeria in the long run. Theoretically, the result is consistent with the market-based view. Higher coefficient (222.2) of FS_R means a system that is capital market-based dominant while a lower FS_R coefficient means more of a bank-based system (Olofin and Afangideh, 2009). The stock market based view posits a significant positive relationship between financial structure (FS_R) and economic growth while the bank-based view predicts a negative significance relationship between financial structure (FS_R) and economic growth. It is important to note that stock market liquidity, as measured by the market capitalization and banking sector activity, as measured by bank credit to private sector are more robust in predicting economic growth. This is inconsistent with the Levine and Zervos (1998) and Saibu et al, (2009) results that market capitalization is not a robust predictor of economic growth. Consequently, the debate between bank based and market based is not a Nigerian phenomenon.

However, for the purposes of this study, it is important to focus on the significance or otherwise of the coefficient of FS_R, rather than its sign (Arestis et al, 2004 and Olofin and Afangideh, 2009). A significant coefficient of FS_R implies that financial structure matters while the reverse is the case. The result posits that the overall financial structure (FS_R) is the most useful way to distinguish financial systems (Levine, 2002) since both bank and stock market system matter in explaining economic growth as against bank-based versus market-based debate. This is consistent with financial services theory as well as Olofin and Afangideh (2009) but inconsistent with Saibu et al, (2009).

Table 11: Multivariate VECM Causality Test (Short Term)

\begin{tabular}{|c|c|c|c|c|c|c|c|c|}
\hline \multirow{2}{*}{$\begin{array}{l}\text { Dependent } \\
\text { Variable }\end{array}$} & \multicolumn{7}{|c|}{ Independent Variable } & \multirow[b]{2}{*}{ ECT(-1) } \\
\hline & $\begin{array}{l}\text { D(LRGD } \\
\text { P) }\end{array}$ & $\mathrm{D}(\mathrm{GLF})$ & $\overline{\mathrm{D}(\mathrm{LDI})}$ & $\begin{array}{l}\mathrm{D}\left(\mathrm{FS} \_\mathrm{R}\right. \\
\end{array}$ & $\begin{array}{l}\text { D(LTGEX_ } \\
\text { R) }\end{array}$ & $\mathrm{D}(\mathrm{OPENN})$ & $\mathrm{D}$ (INF) & \\
\hline $\mathrm{D}$ (LRGDP) & & $\begin{array}{l}0.36350 \\
4\end{array}$ & $\begin{array}{l}0.4650 \\
08\end{array}$ & $\begin{array}{l}1.2251 \\
23\end{array}$ & 0.054826 & 0.042555 & $\begin{array}{l}1.48960 \\
4\end{array}$ & $\begin{array}{l}- \\
0.007709 * \\
*\end{array}$ \\
\hline $\mathrm{D}(\mathrm{GLF})$ & $\begin{array}{l}1.31572 \\
6\end{array}$ & & $\begin{array}{l}0.1078 \\
69\end{array}$ & $\begin{array}{l}0.63850 \\
2\end{array}$ & 0.001995 & 0.028172 & 0.070575 & 0.003715 \\
\hline $\mathrm{D}(\mathrm{LDI})$ & $\begin{array}{l}3.20862 \\
4 * *\end{array}$ & $\begin{array}{l}0.4935 \\
29\end{array}$ & & $\begin{array}{l}2.09791 \\
6\end{array}$ & 0.048394 & 1.121156 & $\begin{array}{l}0.71310 \\
6\end{array}$ & $\begin{array}{l}- \\
0.033223 * \\
* *\end{array}$ \\
\hline$\overline{D\left(F S \_R\right)}$ & $\begin{array}{l}2.42873 \\
8\end{array}$ & $\begin{array}{l}0.6860 \\
79\end{array}$ & $\begin{array}{l}2.52315 \\
4\end{array}$ & & $3.421969 * *$ & 1.738158 & $\begin{array}{l}1.07702 \\
4\end{array}$ & $\begin{array}{l} \\
0.001157^{*} \\
*\end{array}$ \\
\hline $\begin{array}{l}\text { D(LTGEX_ } \\
\text { R) }\end{array}$ & $\begin{array}{l}0.12928 \\
6\end{array}$ & $\begin{array}{l}0.2004 \\
66\end{array}$ & $\begin{array}{l}0.3417 \\
08\end{array}$ & $\begin{array}{l}0.03394 \\
8\end{array}$ & & 0.033132 & $\begin{array}{l}0.00229 \\
4\end{array}$ & -0.008095 \\
\hline $\mathrm{D}(\mathrm{OPENN})$ & $\begin{array}{l}3.18415 \\
2^{* *}\end{array}$ & $\begin{array}{l}2.5516 \\
27\end{array}$ & $\begin{array}{l}0.8235 \\
14\end{array}$ & $\begin{array}{l}0.3269 \\
07\end{array}$ & $4.764959 * *$ & & $\begin{array}{l}2.74369 \\
5 * *\end{array}$ & $\begin{array}{l} \\
0.030222 * \\
*\end{array}$ \\
\hline $\mathrm{D}$ (INF) & $\begin{array}{l}0.11706 \\
2\end{array}$ & $\begin{array}{l}0.4068 \\
42\end{array}$ & $\begin{array}{l}0.44641 \\
2\end{array}$ & $\begin{array}{l}0.6803 \\
21\end{array}$ & 0.702241 & 0.233062 & & 2.156642 \\
\hline
\end{tabular}

$*$ Significant at $1 \%, * *$ significant at $5 \%$ and $* * *$ significant at $5 \%$

Source: calculations by Authors using Eviews 9.

As shown in Table 11, the coefficient on FS_R was not significant on economic growth model in the short run in Nigeria. This reveals that the financial structure is not important in the short run. The results of Table 9 and the short run are different. The short run result shows that the insignificant of FS_R is inconsistent with that of the long run. This could be attributed to gestation gap between finance mobilization, project implementation and the impact of the project. Results of the error correction representation (ECT(-1)), articulate the dynamic behaviour of the VECM model, where the coefficient of the error correction term in growth model is negative and highly significant at $5 \%$ which confirms the existence of the long-run relationship between the underlying variables and represent the speed of adjustment with which the model attains the long-run steady state equilibrium following an exogenous shock in the short-run. In the growth model the ECT(-1) coefficient is about 0.008 percent which is quite slow. This means that the deviation from long-run equilibrium will be corrected by a speed between 0.008 percent every year. Next is model appraisal which aimed at validating the parameter outcomes of the estimated model. 


\subsubsection{Model Appraisal}

The AR roots test result in the appendices indicates that the estimated model is stationary since there are no roots lying outside the unit cycle, meaning that the model is stable. The serial correlation LM test result shows a probability of 0.9113 at lag 1 which is high; therefore, the null hypothesis is rejected and the study concludes that there is no serial correlation among the underlying variables. Also, the normality test result shows an indication of normal distribution. This is because all the probabilities of Skewness, Kurtosis and Jarque-Bera at lag 1 are above $5 \%$ and $10 \%$, hence the null hypothesis of normality is rejected. Furthermore, the hetroscedasticity test reveals that the null hypothesis cannot be rejected since the probability $(0.3685)$ is greater than $5 \%$ and $10 \%$. This, therefore, means that there is no model misspecifications problem.

\section{Conclusion and Policy Recommendations}

This study examined the relationship between financial structure and economic growth in Nigeria. As lead up to financial structure and economic growth relationship analysis, the competing theoretical views of bank and market based financial system, and economic growth is explored. The results of the study show that stock market-based has a positive significant effect on growth while bank-based has a negative significant effect on growth. This implies that both bank-based and market-based are substitute, therefore, market-based financial system is better at enhancing economic growth. However, the study focuses on the significance of coefficients of financial development variables (bank-based and market-based), rather than their signs. Given the bank and market system variables, it shows that the both are significantly influencing economic growth in Nigeria. The significant of the coefficients of both bank and stock market variables imply that both systems matter in explaining economic growth in Nigeria, thereby favouring their combination. The result of the study also reveals that financial structure which captures the combination of stock market-based and bank-based financial development has a positive significant effect on growth. The coefficient of financial structure has a positive sign, significant and very high. This is consistent with the stock market view. Higher coefficient of financial structure means a system that is capital market-based dominant while a lower financial structure coefficient means more of a bank-based system. The stock market based view posits a significant positive relationship between financial structure and economic growth while the bankbased view predicts a negative significance relationship between financial structure and economic growth. However, for the purposes of this study not to be defeated, the study focuses on the significance or otherwise of the coefficient of financial structure, rather than its sign and magnitude. A significant coefficient of financial structure implies that financial structure matters in explaining growth. Therefore, the study posits that the overall financial structure is the most useful way to assess the financial systems since both bank and stock market system matter in explaining economic growth as against bank-based versus market-based debate. The result is consistent with the financial services view that both bank and stock market are relevant to the economic growth in Nigeria. Based on the empirical evidence, the study therefore recommends that there should be continuous holistic reforms of both banking and stock market simultaneously, as the development in one sector has a neglect effect on the other. None of the sectors should be excluded for reforms aimed at overall development of the financial system and the economy as a whole.

\section{References}

Allen, F. and Gale, D. (1999). Comparing Financial Systems. Cambridge, Mass.: MIT Press.

Arestis, P., Demetriades, P. and Luintel, K. (2001). Financial Development and Economic Growth: The Role of Stock Markets. Journal of Money, Credit, and Banking, 33(1):16-41.

Arestis, P., Luintel, A. D. and Luintel, K.B. (2004). Does Financial Structure Matter?The Levy Economics Institute of Bard College, Annandale-on-Hudson, NY.

Ayadi, R., Arbak, E., Ben-Naceur, S. and De-Groen, W. P. (2013). Financial Development, Bank Efficiency and Economic Growth across the Mediterranean. Medpro Technical Report No. 30.

Beck, T. and Levine, R. (2002).Stock Markets, Banks and Growth: Panel Evidence.NBER Working Paper Series No. 9082. Cambridge, Mass.: National Bureau of EconomicResearch.

Bhide, A. (1993). The Hidden Costs of Stock Market Liquidity. Journal of FinancialEconomics, 34(1): 1-51.

Boot, A.W.A., Greenbaum, S.Y. and Thakor, A.V. (1993) Reputation and Discretion in Financial Contracting, American Economic Review, Vol. 83, pp.1165-1183.

Boyd, J. H. and Prescott, E. C. (1986). Financial Intermediary-Coalitions. Journal ofEconomic Theory, 38(2): 211232.

Boyd, J. H. and Smith, B. D. (1998). The Evolution of Debt and Equity Markets in Economic Development. Economic Theory, 12: 519-560.

Caporale, G.C., Howell, G.A. and Soliman, A.M. (2002). Stock Market Development and Economic Growth: The Causal Linkage: Discussion Paper, Centre of Monetary and Financial Economics, South Bank University London. 
Cental Bank of Nigeria Statistical Bulletin, Various Issues.

Demirguc-Kunt, A. and Levine, R. (1996). Stock Markets, Corporate Finance and Economic Growth: An Overview, World Bank Economic Review, Vol. 10, No. 2, Pp.223-239.

Demirguc-Kunt, A. and Levine, R. (2001). Financial Structures and Economic Growth: A Cross-Country Comparison of Banks, Markets and Development, Cambridge, Mass.:MIT Press.

Dickey, D. A. and Fuller, W. A (1979). Distributions of the Estimators for Autoregressive Time Series With a Unit Root. Journal of American Statistical Association, 74, 427-431.

Gerschenkron, A. (1962). Economic Backwardness in Historical Perspective, A Book of Essays. Cambridge, Mass: Harvard University press, Cambridge, MA.

Goldsmith, R. (1969). Financial Structure and Development, New Haven, Yale University Press, CY.

Harris, R. D. F. (1997). Stock Markets and Development: A Reassessment. European Economic Review, 41: 139146.

Hellwig, M. (1991). Banking, Financial Intermediation and Corporate Finance. European Financial Integration, 35, 63

Hellwig, M. (1998). On The Economics and Politics of Corporate Finance and Corporate Control, Sonderforschungsbereich 504 Publications, University of Mannheim.

Hoshi, T., Kashyap, A.and Scharfstein, D. (1991). Corporate Structure, Liquidity and Investment: Evidence from Japanese Industrial Groups. Quarterly Journal of Business and Economics, 106: 678-709.

Johansen, S. and Juselius, K.(1991). Testing Structural Hypothesis in a Multivariate Cointegration Analysis. Journal of Econometrics, Vol. 53, p.21

La Porta, R, Lopez-de-Silanes, F., Shleifer, A. and Vishny, R.W. (1997). Legal Determinants of External Finance. Journal of Finance, 52: 1131-1150.

La Porta, R., Lopez-de-Silanes, F., Shleifer, A. and Vishny, R. W. (1998). Law and Finance. Journal of Political Economy, 106(6): 1113-1155

Levine, R. (1997). Financial Development and Economic Growth: Views and Agenda. Journal of Economic Literature, Vol. 35, No. 2, pp.688-726.

Levine, R. (2001). International Financial Liberalization and Economic Growth. Review of International Economics, 9, 688-702

Levine, R. (2002) Bank Based or Market Based Financial System Which is Better?, Working Paper Carlson School University of Minnesota.

Levine, R. (2003). More on Finance and Growth: More Finance More Growth? Federal Reserve Bank of St. Louis Review, 85 (4): 31-46.

Levine, R. and Zervos, S. (1998). Stock Markets, Banks and Economic Growth. American Economic Review, 88 (3): 537-558.

Luintel, K. B. and Khan, M. (2002). Are International R\&D Spillovers Costly for the U.S.? Discussion Paper, Department of Economics and Finance: Brunel University.

Luintel, K. B., Khan, M., Arestis, P. and Theodoridis, K.(2008). Financial Structure and Economic Growth. Cardiff Economics Working Papers/ Cardiff Business School Working Paper Series, E2008/3.

Merton, R. C. (1995). A Functional Perspective of Financial Intermediation. Financial Management, $24:$ 23-41.

Merton, R. C. and Bodi, Z. (1995). A Conceptual Framework for Analysing the Financial Environment. In D.B. Crane et al (eds.), The Global Financial System: A Functional Perspective. Boston, Mass.: Harvard Business School.

Mork, R. and Nakkamura, M. (1999). Banks and Corporate Control in Japan. Journal of Finance, 54: $319-340$.

Olofin, S.O and Afangideh, U.J. (2009). Financial Structure and Economic Growth in Nigeria: A Macroeconometric Approach\|, Centre for Econometric and Allied Research (CEAR)

Phillips, P., \& P. Perron, P. (1988). Testing For A Unit Root In Time Series Regression. Biometrica, 75, 333-346.

Rajan, R. (1992). Insiders and Outsiders: The Choice Between Informed and Armies Length Debt. Journal of Finance, Vol. 47, No. 4, pp.1367-1400.

Saibu, O M, Bowale, K. I E. and Akinlo, A. E. (2009).Financial Structure and Economic Growth: Empirical Evidence from Nigeria. International Journal of Business and Emerging Markets, Vol. · January, Inderscience Enterprises Ltd.

Security and Exchange Commission Statistical Bulletin (2017), Vol. 1.2, June.

Stiglitz, J. E. (1985). Credit Markets and the Control of Capital. Journal of Money, Credit and Banking, 17 (1): 133152. 
Stulz, R. M. (2000). Financial Structure, Corporate Finance and Economic Growth.International Review of Finance, $1,11-38$.

Stulz, R. M. (2001). Does Financial Structure Matter for Economic Growth? A Corporate Finance Perspective. In Financial Structure and Economic Growth: A Cross-Country Comparison of Banks, Markets, and Development, eds. A Demirguc-Kunt, R Levine. Cambridge, MA:MIT Press.

Tadesse, S. (2000). Financial Architecture and Economic Performance: International Evidence, Working Paper, University of South Carolina.

Ujunwa, A., Salami, O.P., Nwakoby, I. and Umar, A. H. (2012). Financial Structure and Economic Growth in Nigeria: Theory and Evidence. International Journal of Economics and Finance, Vol. 4, No. 4; April. Published by Canadian Center of Science and Education

Weinstein, D. E. and Yafeh, Y. (1998). On the Costs of a Bank-Centered Financial System: Evidence from the Changing Bank Relations in Japan. Journal of Finance, 53: 635-672.

Wenger, E. and Kaserer, C. (1998). The German System of Corporate Governance: A Model Which Should not be Imitated." In S.W. Black and M. Moersch (eds.), Competition and Convergence in Financial Markets: The German and Anglo-American Models. New York: North Holland.

World Bank (2001). Finance for Growth: Policy Choices in a Volatile World. A World Bank Policy Research Report. Washington D.C.: World Bank.

World Development Indicators (WDI).

\section{Appendices}

Inverse Roots of AR Characteristic Polynomial

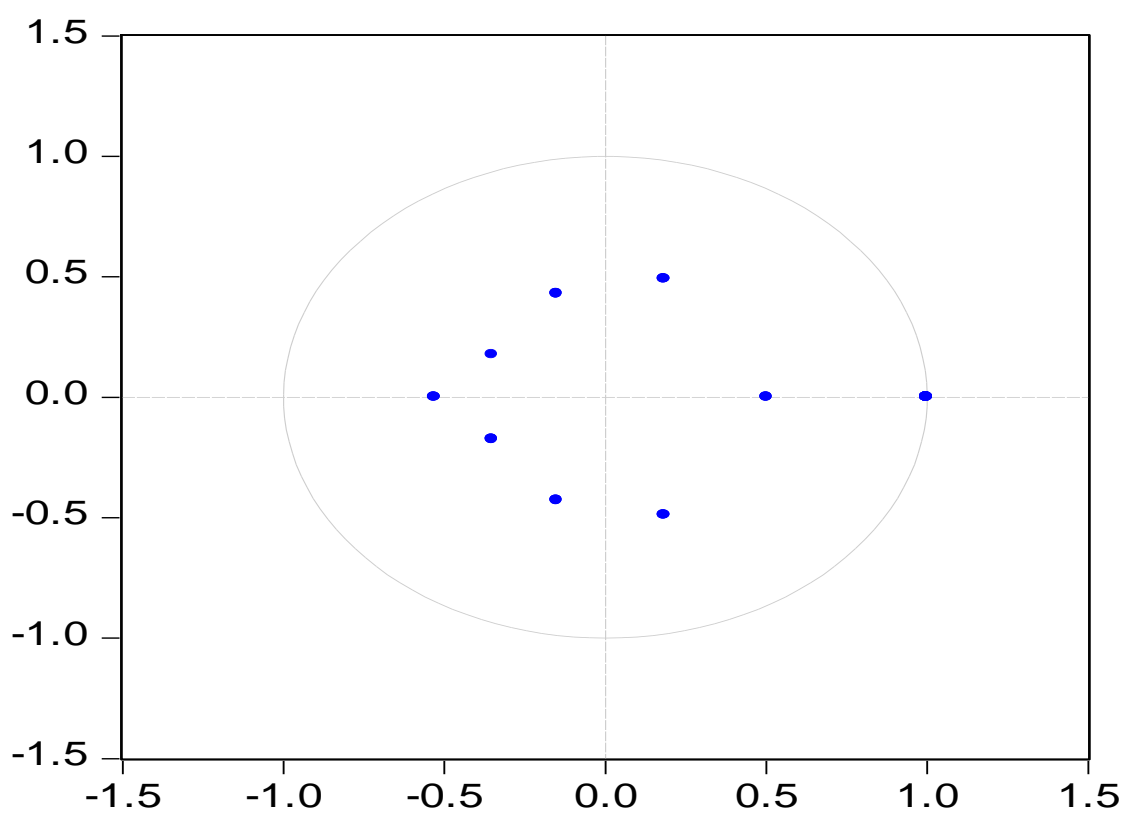

AR ROOTS GRAPH OF FINANCIAL STRUCTURE AND GROWTH

Source: calculations by Authors using Eviews 9.

VEC Residual Serial Correlation LM Tests of FS_R and Growth

\begin{tabular}{lll}
\hline Lags & LM-Stat & Prob \\
\hline 1 & 36.26966 & 0.9113 \\
\hline 2 & 51.68200 & 0.3695 \\
\hline
\end{tabular}

* Probs from chi-square with $49 \mathrm{df}$. ** Null Hypothesis: no serial correlation at lag order $\mathrm{h}$

Source: calculations by Authors using Eviews 9.

Residual Normality Test of FS_R and Growth

Chi-sq P value




\begin{tabular}{lcc}
\hline Skewness & 0.059595 & 0.8071 \\
\hline Kurtosis & 0.338092 & 0.5609 \\
\hline Jarque-Bera & 0.397687 & 0.8197 \\
\hline
\end{tabular}

*Null Hypothesis: residuals are multivariate normal

Source: calculations by Authors using Eviews 9.

Hetroscedasticity Test (White test with no cross terms) of FS_R and Growth

\begin{tabular}{ccc}
\hline & Joint Test: & \\
\hline Chi-sq & Df & Prob. \\
\hline 457.4501 & 448 & 0.3685 \\
\hline
\end{tabular}

*The null hypothesis: there is no heteroskedesticity

Source: calculations by Authors using Eviews 9.

\section{Copyrights}

Copyright for this article is retained by the author(s), with first publication rights granted to the journal. This is an open-access article distributed under the terms and conditions of the Creative Commons Attribution license (http://creativecommons.org/licenses/by/4.0/). 